\author{
Przemysław ŚLESZYŃSKI \\ Dr hab., prof. PAN, Instytut Geografii i Przestrzennego Zagospodarowania Polska Akademia Nauk, Warszawa \\ psleszyn@twarda.pan.pl
}

\title{
WSPÓŁCZESNE I PROGNOZOWANE UWARUNKOWANIA DEMOGRAFICZNO-MIGRACYJNE W ROZWOJU MIEJSKIEGO SYSTEMU OSADNICZEGO POLSKI
}

\begin{abstract}
Abstrakt: W artykule przedstawiono uwarunkowania demograficzno-migracyjne w największym stopniu kształtujące współczesny rozwój krajowego systemu osadniczego. Badania wskazują na kształtowanie się hierarchii miast w zakresie powiązań migracyjnych, a prognozy demograficzne dość jednoznacznie pokazują depopulację miast, zwłaszcza średnich i ich zapleczy. Przy tym skala depopulacji jest i tak silnie niedoszacowana ze względu na nierejestrowany exodus Polaków za granicę w poszukiwaniu pracy i lepszych warunków życia. W tym kontekście zaprezentowano szacunki zmian liczby ludności uwzględniające nierejestrowaną emigrację zagraniczną. Na zakończenie zostały sformułowane wnioski, w tym dla planowania rozwoju i polityki osadniczej w warunkach depopulacji kraju. Niektórych procesów nie da się już zatrzymać ani odwrócić i konieczne jest łagodzenie ich negatywnych skutków dla systemu osadniczego.

Słowa kluczowe: krajowy system osadniczy, rozwój demograficzny, migracje wewnętrzne, migracje zagraniczne, prognozy demograficzne, depopulacja, kurczenie się miast, hierarchia funkcjonalna.

\section{CONTEMPORARY AND FORECASTING DEMOGRAPHIC-MIGRATION CONDITIONS OF THE DEVELOPMENT OF THE POLISH SETTLEMENT SYSTEM}

Abstract: The writer presents the demographic and migration conditions shaping the contemporary development of the national settlement system. Research indicates the formation of the hierarchy of towns and cities in terms of migration linkages. Demographic forecasts show quite clearly depopulation of cities, especially the medium-sized ones and support facilities. At this scale depopulation is strongly underestimated due to the unregistered exodus of Poles abroad in search of work and better living conditions. In this context, its presented estimates of population change, taking into account unregistered foreigner out-flow. At the end conclusions were conclusions for development planning and settlement policy.

Keywords: national settlement system, demographic development, internal migration, demographic forecast, depopulation, shrinking cities, functional hierarchy.
\end{abstract}

\section{WPROWADZENIE}

W Polsce w ostatnich trzech dekadach zachodzą poważne zmiany w systemie osadniczym, związane z jego wewnętrzną strukturą i hierarchią. Procesy transformacji społeczno-gospodarczej po 1989 r., nowy podział administracyjny od 1999 r., wejście Polski do Unii Europejskiej w 2004 r. (i w efekcie otwarcie różnego rodzaju rynków) oraz odwrócenie trendów demograficznych powodują różnicowanie potencjału społeczno-ekonomicznego poszczególnych miast oraz przesunięcia w ich wzajemnych relacjach i oddziaływaniach zależnych od lokalizacji działalności gospodarczej oraz atrakcyjności miejsc pracy i zamieszkania. Uzasadnione staje się pytanie o kierunki i skutki tych zmian, w tym w kontekście rozwoju społeczno-gospodarczego i polityki regionalnej.

Zmiany liczby ludności miast dokonywały się dotychczas wskutek dużych i dodatnich różnic w pozio- mie zgonów i urodzeń oraz zwłaszcza ruchu wędrówkowego. W warunkach polskich, wobec wyrównanego lub słabo ujemnego w ostatniej dekadzie salda ruchu naturalnego (w grupie wszystkich miast), podstawowym czynnikiem różnicującym stały się migracje. Celem opracowania było zatem nakreślenie odpowiedzi na postawione pytania związane $\mathrm{z}$ tymi uwarunkowaniami.

$\mathrm{W}$ artykule wykorzystano wyniki badań prowadzonych w Instytucie Geografii i Przestrzennego Zagospodarowania Polskiej Akademii Nauk ${ }^{1}$ w różnych programach naukowych i naukowo-praktycznych. Podczas prezentacji empirycznej oparto się m.in. na międzygminnych macierzach rejestrowanych migracji (zameldowań i wymeldowań), statystyce Banku Danych Lokalnych pochodzących z rejestracji bieżącej oraz danych z dwu ostatnich spisów powszechnych (2002 i 2011). 


\section{PROBLEMY ŹRÓDŁOWO- -STATYSTYCZNE}

Badania współczesnych ruchów migracyjnych są utrudnione ze względu na brak rejestracji całości tych zdarzeń. Najbardziej ułomna jest statystyka migracji zagranicznych, która w wielu regionach kraju obejmuje zaledwie kilka procent faktycznych przemieszczeń. W roku 2015 według BAEL 2,3 mln mieszkańców Polski przebywało powyżej trzech miesięcy poza granicami kraju (GUS 2015), podczas gdy np. w latach 19902014 na stałe wymeldowało się za granicę zaledwie 603 tys. osób, z czego 291 tys. w latach 2004-2014. Wielu badaczy zwraca uwagę, że to niedoszacowanie statystyki sięga jeszcze lat 80. ubiegłego wieku (Kędelski 1990), w tym w przypadku wyjazdów do Niemiec niezarejestrowanych przez gminne ewidencje mogą sięgać aż 700-800 tys. osób (Sakson 1998). P. Korcelli (1995a) podaje, że według GUS z byłego województwa warszawskiego w latach 1981-1988 wyjechało 3 tys. osób, podczas gdy dane ówczesnej Rządowej Komisji Ludnościowej na podstawie przekroczeń paszportowych mówiły o 76 tys. osób przebywających na „Zachodzie" oraz że około $80 \%$ tej populacji pozostawało tam na stałe.

Mniejszym, ale równie istotnym błędem są obarczone migracje wewnętrzne. Tutaj prawidłowością jest niedoszacowanie stanów ludnościowych stref podmiejskich i generalnie najbardziej atrakcyjnych pod względem pracy i zamieszkania aglomeracji, z warszawską na czele, oraz przeszacowanie regionów peryferyjnych (Śleszyński 2011a, 2014a). Największe różnice dotyczą najbardziej mobilnych kategorii wieku (20-35 lat). Przykładowo, porównanie rejestracji bieżącej z 2001 r. i danych ze spisu powszechnego 2002 pokazało, że w niektórych gminach peryferyjnych i podmiejskich różnice dotyczą nawet 20\% tej populacji (Śleszyński 2005). Gminom peryferyjnym nie zależy jednak na solidnej weryfikacji ewidencji bieżącej, gdyż mogłoby się to wiązać z utratą wpływów subwencji budżetowej uzależnionej od liczby mieszkańców. Z kolei gminy podmiejskie tracą $\mathrm{z}$ tego powodu wpływy podatkowe, zwłaszcza z tytułu PIT.

Generalnie, kwestia nieprawidłowego oszacowania stanów ludności oraz zdarzeń migracyjnych w Polsce i wpływu tych czynników na rzeczywiste procesy demograficzne jest złożona, ale istnieje już pewna literatura na ten temat (Sakson 1998, Kupiszewski 2002, Śleszyński 2005, 2011a, Paradysz 2009, Iglicka 2011, Eberhardt 2012, Dehnel, Gołata 2013, Gołata 2013,
Jończy 2014). Niewątpliwie wyzwaniem dla statystyki publicznej $\mathrm{w}$ tym zakresie są plany zniesienia tzw. obowiązku meldunkowego i zastąpienie tej procedury alternatywnymi źródłami administracyjnymi. Może to pogorszyć i tak już niezadowalającą statystykę związaną z przepływami ludności.

\section{CZYNNIKI DEMOGRAFICZNO- -MIGRACYJNE}

Głębokie zmiany polityczne i społeczno-gospodarcze po 1989 r. oraz uwarunkowania związane z falowaniem niżów i wyżów demograficznych wywołały zmiany $\mathrm{w}$ demograficznych i migracyjnych podstawach rozwoju miast. Wprowadzenie mechanizmów rynkowych spowodowało „szok transformacyjny”, który dla systemu osadniczego oznaczał ubytek lub reorganizację miejsc pracy. Dezindustrializacja i pojawienie się masowego bezrobocia skutkowały osłabieniem mobilności wewnętrznej i wzmocnieniem nierejestrowanej emigracji zagranicznej, szacowanej na 0,5-1,3 mln osób (Korcelli 1995b, przy tym znaczna część osób wyemigrowała jeszcze w latach 80.). Emigracji zagranicznej sprzyjała nadwyżka miejsc pracy w rolnictwie, wynikająca m.in. ze słabej (na tle państw zachodnich), urbanizacji Polski.

Po roku 1989 demograficzny wzrost miast został praktycznie zahamowany (Gawryszewski 2011, Długosz 2005, 2006, Runge 2013, Szukalski 2014, Długosz, Biały 2015), przynajmniej w świetle „oficjalnej” statystyki (rys. 1). Jest bowiem wiele dowodów, że liczba ludności najbardziej atrakcyjnych pod względem pracy i zamieszkania ośrodków (zwłaszcza Warszawy) jest niedoszacowana (Korcelli 1995a, Śleszyński 2005, 2011a), podobnie jak przeszacowana może być liczba ludności małych miast, zwłaszcza w regionach peryferyjnych (Szymańska, Grzelak-Kostulska 2005, Jończy 2010, Jażewicz 2013). Nie zmienia to jednak ogólnego trendu, związanego z wyraźnym wyhamowaniem lub niekiedy odwróceniem wzrostu, nazywanego „kurczeniem się" miast (Kantor-Pietraga 2014, Jaroszewska, Stryjakiewicz 2014) ${ }^{2}$. Wśród towarzyszących temu procesów najbardziej charakterystyczne jest postarzanie struktury wieku populacji (Kurek 2002). Na tle poprzednich dekad Polska wkracza w zupełnie nową fazę rozwoju, czy raczej recesji demograficznej (Eberhardt 2014).

Nowe miejsca pracy i generalnie najsilniejszy rozwój gospodarczy w pierwszym okresie transformacji 
dotyczył największych aglomeracji, z Warszawą na czele (Parysek 2005). Powodowało to selektywne zapotrzebowanie na wykwalifikowane zasoby pracy i tym samym drenaż wewnętrzny osób lepiej wykształconych, o określonych kompetencjach. W dalszym okresie znaczenie największych miast jeszcze bardziej rosło, a ich pozycję $\mathrm{w}$ systemie osadniczym dodatkowo wzmocniła reforma administracyjna z 1999 r. Zbiegło się to $\mathrm{w}$ czasie $\mathrm{z}$ wchodzeniem $\mathrm{w}$ wiek produkcyjny osób, urodzonych podczas wyżu demograficznego w latach 70. i 80. ubiegłego wieku. Osoby te w dużej mierze „zasiliły” największe miasta, ale nadwyżka osób z regionów, które nie mogły „wchłonąć” wyżu demograficznego, wyjechała także za granicę w poszukiwaniu pracy, czemu sprzyjało zapowiadane i zrealizowane otwarcie rynków pracy w Europie Zachodniej (zwłaszcza w Irlandii i Wielkiej Brytanii), jak też pewne tradycje migracyjne i silne związki z niektórymi rozwiniętymi krajami (głównie Niemcy, Belgia, Stany Zjednoczone).

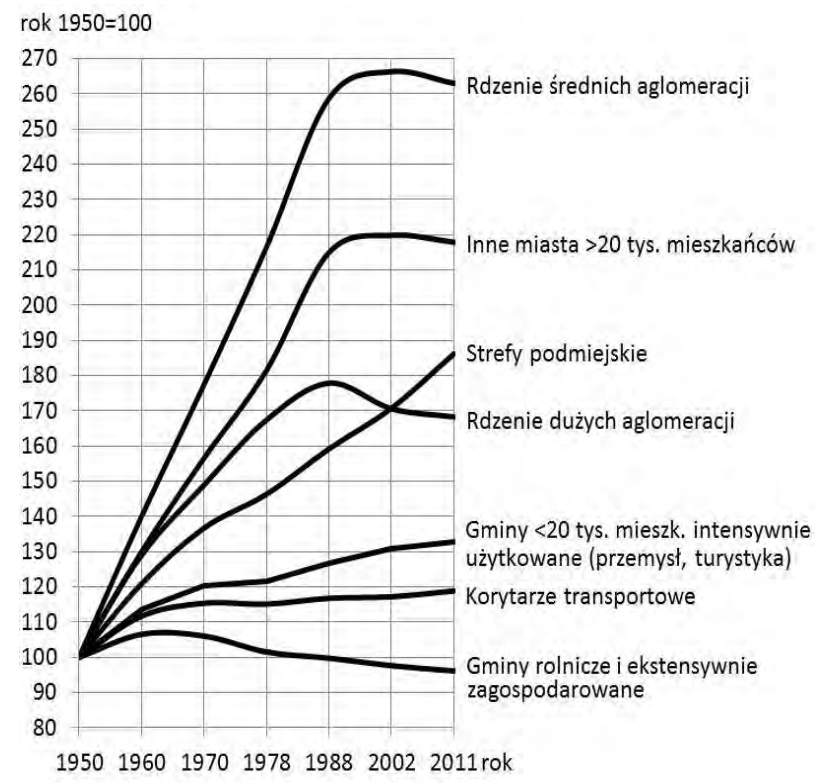

Rys. 1. Zmiany w rejestrowanej liczbie ludności w latach 1950-2011 według kategorii gmin

Źródło: opracowanie własne na podstawie spisów powszechnych ludności

Rola emigracji zagranicznej stała się kluczowa w kształtowaniu liczby ludności miast. Jej wpływ był dwojaki: bezpośredni i pośredni. Po pierwsze nastąpił odpływ mieszkańców na pobyt identyfikowany jako „czasowy powyżej 12 miesięcy”, co wprost skutkowało obniżeniem liczby ludności, jak też zmniejszoną płodnością (migrują głównie osoby w wieku produkcyjnym mobilnym). Po drugie odpływ z regionów źródłowych, mając charakter konkurencji w stosunku do dotychczasowych kierunków przemieszczeń, skutkuje zmniejszeniem bazy migracyjnej w przyszłości. Jest to istotne zwłaszcza dla największych miast, czerpiących migrantów ze swoich „zlewni” migracyjnych, które na ogół pokrywają się z granicami województw, a w przypadku Warszawy obejmują cztery województwa: mazowieckie, warmińsko-mazurskie, podlaskie i lubelskie (Śleszyński 2011). Ostatnie szczegółowe dane z NSP 2002 według gmin pokazują, że szczególnie „wydrenowane” zostały Opolszczyzna, Podlasie, Podkarpacie, Warmia i Mazury (Śleszyński 2013). Stanowi to osłabienie bazy migracyjnej zwłaszcza dla Olsztyna, Białegostoku, Warszawy, Lublina i Rzeszowa.

Od około 2000 r. wewnątrz kraju doszedł jeszcze jeden czynnik, związany z potencjałem demograficznym miast, jakim stała się silna wewnętrzna dekoncentracja demograficzna. O ile wcześniej zjawisko suburbanizacji dotyczyło głównie największych aglomeracji, to w ostatnim okresie notuje się również silny napływ ludności do stref podmiejskich mniejszych miast. Przepływy z rdzeni miejskich powyżej 20 tys. mieszkańców do ich stref zewnętrznych w 2009 r. stanowiły już 22,1\% wszystkich rejestrowanych przemieszczeń (Śleszyński 2014b). Zjawisko tej wewnętrznej dekoncentracji wynika zarówno z przyczyn ekonomicznych (bogacenie się społeczeństw, ale też często niższe ceny mieszkań lub znacznie wyższy standard za tę samą cenę), społecznych (prestiż zamieszkania), jak też przyrodniczych (jakość życia) - por. np. A. Zborowski, P. Raźniak (2013). Możliwości zamieszkania pod miastem sprzyja nadpodaż tam gruntów budowlanych, prowadząca do rozpraszania zabudowy, wynikająca ze złego prawa planistycznego (Kowalewski i in. 2014, Śleszyński i in. 2016).

Aktualnie procesy suburbanizacji są jedną z poważniejszych przyczyn zmniejszania się liczby ludności miast. Warto jednak zwrócić uwagę, że spadek ludności powodowany tym czynnikiem nie musi być traktowany w kategoriach zagrożenia ekonomicznego, bowiem opuszczająca miasta ludność pozostaje z nim w silnym związku funkcjonalnym. Badania pokazują także, że w przestrzennej redystrybucji ludności i profilach gęstości zaludnienia charakterystyczny „krater” dotyczył znikomej części średnich i dużych miast Polski (Śleszyński 2014c).

Okres od 1989 r. do czasów współczesnych nie jest zatem jednorodny i można w nim wyróżnić, z punktu widzenia rozwoju demograficzno-migracyjnego miast, kilka charakterystycznych podokresów: 
a) lata od 1989 do około 1995 r., kiedy nastąpiła silna reorganizacja rynków pracy, w tym pojawienie się masowego bezrobocia przy spadku ogólnej liczby miejsc zatrudnienia; był to czynnik ograniczający mobilność wewnętrzną, a sprzyjający emigracji zagranicznej, w większości nierejestrowanej;

b) lata od 1995 do około 2004 r., kiedy miała miejsce dosyć silna polaryzacja rozwoju, wyodrębniła się wtedy już wyraźna czołówka kilku największych aglomeracji (z Warszawą na czele), skutecznie przyciągających migrantów; czynnikiem wzmacniającym mobilność było wchodzenie w okres dorosłości roczników z wyżu demograficznego lat 1974-1983;

c) czasy po 2004 r., charakteryzujące się pogłębianiem procesów polaryzacji, kurczeniem się zasobów migracyjnych i różnicowaniem się zbioru miast pod względem atrakcyjności jako miejsca pracy i zamieszkania oraz intensyfikacją procesów dekoncentracji wewnętrznej; ten ostatni proces dotyczył nie tylko największych aglomeracji, lecz także ośrodków niższego rzędu, w tym lokalnych.

Czynnikiem, który mógłby w znacznym stopniu wpłynąć na zmiany liczby ludności jest silniejszy wzrost imigracji zagranicznej. Jest to w chwili obecnej jedyny realny sposób powstrzymania niekorzystnych procesów społeczno-demograficznych, związanych m.in. $\mathrm{z}$ prognozowanymi niedoborami na rynkach pracy. Zjawisko to jest pożądane, o ile imigranci mogą podlegać asymilacji i integracji kulturowej. Dotychczasowe obserwacje są obiecujące, gdyż główna fala napływu migrantów zarobkowych pochodzi z krajów b. ZSRR, w tym zwłaszcza Ukrainy. Według oficjalnych danych Ministerstwa Rodziny, Pracy i Polityki Społecznej, w latach 2012-2014 wydawano 391436 tys. pozwoleń na pracę rocznie ( $\mathrm{z}$ tendencją rosnącą), w zdecydowanej większości obywatelom Ukrainy (95-98\%), a nieoficjalne szacunki (w tym „oficjalne” wypowiedzi ambasadora Ukrainy) z początku 2016 r. mówią nawet o około $1 \mathrm{mln}$ pracujących. Może to być istotne uzupełnienie przewidywanych ubytków demograficznych, a ze względu na bliskość geograficzną - korzystne dla systemu osadniczego Polski Wschodniej, najbardziej zagrożonego wyludnianiem miast.

Co więcej, dotychczasowe obserwacje wskazują, że napływ imigrantów ukraińskich wydaje się szczególnie pożądany ze względu na fakt, że podejmują oni pracę także w mniejszych miastach. Taki model imigracji byłby zasadniczo odmienny od spotykanego w Europie Zachodniej, który dotyczy w pierwszej kolejności największych aglomeracji, zarówno ich obszarów cent- ralnych, jak i przedmieść. Odmienności lokalizacji przestrzennej imigrantów w Polsce towarzyszy zapewne większe podobieństwo kulturowe.

\section{KIERUNKI I NATĘŻENIE WSPÓŁCZESNYCH REJESTROWANYCH MIGRACJI WEWNĘTRZNYCH}

Na kolejnych rysunkach przedstawiono główne powiązania migracyjne w roku 2012. Rysunek 2 ujawnia dominującą rolę Warszawy w organizacji stałych przemieszczeń wewnątrz kraju. Przemieszczenia do i z Warszawy w 2012 r. stanowiły 8,1\% wszystkich zarejestrowanych migracji wewnętrznych (w wartościach bezwzględnych było to 32,0 tys.). Co istotne, stolica ma nie tylko największą zlewnię migracyjną, ale też skutecznie konkuruje z innymi dużymi miastami; przykładowo - ze wszystkimi stolicami województw ma dodatni bilans migracyjny (Śleszyński 2011b). Faktyczna skala miracji jest większa, bowiem kilka szacunków wskazuje na 80-250 tys. niezameldowanej ludności (Śleszyński 2011a).

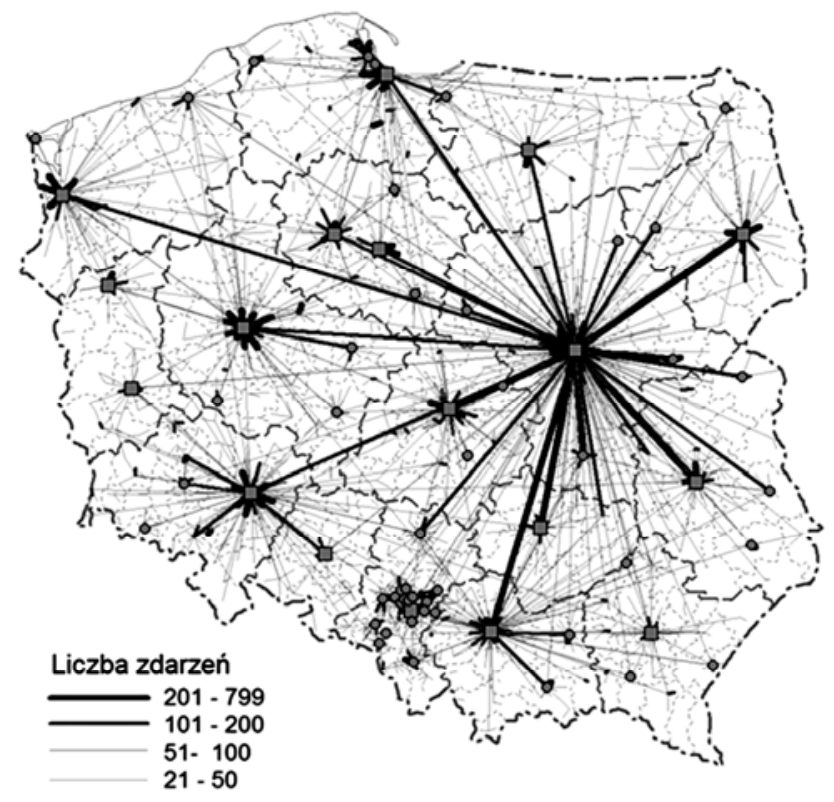

Rys. 2. Rejestrowane międzygminne przemieszczenia migracyjne w $2012 \mathrm{r}$.

Źródło: na podstawie danych GUS

Tabela 1 pokazuje przepływy pomiędzy kategoriami gmin, wyróżnionymi ze względu na funkcje. Napływ do rdzeni wojewódzkich stanowili głównie mieszkańcy innych miast w tej kategorii, a następnie stref podmiejskich i ośrodków miejskich niższego rzędu - łącznie było to ponad 50\% migrantów. Przepływy te 
Tab. 1. Rejestrowane przepływy migracyjne pomiędzy kategoriami gmin w 2012 r.

\begin{tabular}{|c|c|c|c|c|c|c|c|c|c|c|c|}
\hline \multirow{2}{*}{ Kategoria } & A & $\mathrm{B}$ & $\mathrm{C}$ & $\mathrm{D}$ & $\mathrm{E}$ & $\mathrm{F}$ & G & $\mathrm{H}$ & I & $\mathrm{J}$ & $\sum$ \\
\hline & \multicolumn{11}{|c|}{ w tysiącach } \\
\hline A - rdzenie $\mathrm{MOF}^{\mathrm{a})}$ stolic województw & 18,3 & 44,9 & 3,7 & 2,1 & 3,8 & 1,7 & 2,4 & 2,9 & 5,6 & 2,3 & 87,8 \\
\hline B - strefy zewnętrzne MOF stolic województw & 17,0 & 15,8 & 1,3 & 0,8 & 1,7 & 1,0 & 1,1 & 1,5 & 3,2 & 1,0 & 44,5 \\
\hline $\mathrm{C}$ - rdzenie MOF miast subregionalnych & 10,4 & 3,5 & 2,4 & 15,7 & 1,8 & 1,2 & 1,4 & 2,8 & 4,8 & 1,3 & 45,4 \\
\hline $\mathrm{D}$ - strefy zewnętrzne MOF miast subregionalnych & 3,1 & 1,3 & 8,4 & 4,4 & 0,9 & 0,6 & 0,6 & 1,0 & 2,3 & 0,7 & 23,0 \\
\hline E - miasta - ośrodki wielofunkcyjne & 10,3 & 4,0 & 2,7 & 1,0 & 2,5 & 2,3 & 2,3 & 4,3 & 8,8 & 2,1 & 40,1 \\
\hline F - gminy z rozwiniętą funkcją transportową & 2,6 & 1,5 & 1,1 & 0,6 & 1,8 & 1,5 & 0,6 & 0,8 & 2,1 & 0,5 & 13,1 \\
\hline $\begin{array}{l}\text { G - gminy o innych rozwiniętych funkcjach } \\
\text { pozarolniczych }\end{array}$ & 3,7 & 1,9 & 1,5 & 0,7 & 2,1 & 0,7 & 2,8 & 1,1 & 2,3 & 1,0 & 17,8 \\
\hline $\mathrm{H}$ - gminy z intensywnie rozwiniętą funkcją rolniczą & 5,9 & 3,2 & 3,7 & 1,2 & 4,8 & 1,0 & 1,2 & 6,3 & 3,7 & 1,1 & 32,2 \\
\hline I - gminy z umiarkowanie rozwiniętą funkcją rolniczą & 9,1 & 5,0 & 5,1 & 2,7 & 7,4 & 2,1 & 2,4 & 3,2 & 9,7 & 2,3 & 49,0 \\
\hline J - gminy ekstensywnie zagospodarowane & 3,5 & 1,9 & 1,5 & 0,8 & 2,0 & 0,6 & 1,2 & 1,1 & 2,4 & 2,2 & 17,3 \\
\hline \multirow[t]{2}{*}{ Razem } & 83,8 & 82,9 & 31,3 & 30,1 & 28,8 & 12,5 & 15,9 & 25,1 & 45,0 & 14,6 & 370,1 \\
\hline & \multicolumn{11}{|c|}{$\mathrm{w} \%$ (wszystkie przepływy międzygminne = 100\%) } \\
\hline A - rdzenie MOF stolic województw & 4,9 & 12,1 & 1,0 & 0,6 & 1,0 & 0,5 & 0,7 & 0,8 & 1,5 & 0,6 & 23,7 \\
\hline B - strefy zewnętrzne MOF stolic województw & 4,6 & 4,3 & 0,4 & 0,2 & 0,5 & 0,3 & 0,3 & 0,4 & 0,9 & 0,3 & 12,0 \\
\hline $\mathrm{C}$ - rdzenie MOF miast subregionalnych & 2,8 & 0,9 & 0,6 & 4,3 & 0,5 & 0,3 & 0,4 & 0,8 & 1,3 & 0,4 & 12,3 \\
\hline D - strefy zewnętrzne MOF miast subregionalnych & 0,8 & 0,3 & 2,3 & 1,2 & 0,2 & 0,2 & 0,1 & 0,3 & 0,6 & 0,2 & 6,2 \\
\hline E - miasta - ośrodki wielofunkcyjne & 2,8 & 1,1 & 0,7 & 0,3 & 0,7 & 0,6 & 0,6 & 1,2 & 2,4 & 0,6 & 10,8 \\
\hline F - gminy z rozwiniętą funkcją transportową & 0,7 & 0,4 & 0,3 & 0,2 & 0,5 & 0,4 & 0,2 & 0,2 & 0,6 & 0,1 & 3,5 \\
\hline $\begin{array}{l}\mathrm{G} \text { - gminy o innych rozwiniętych funkcjach } \\
\text { pozarolniczych }\end{array}$ & 1,0 & 0,5 & 0,4 & 0,2 & 0,6 & 0,2 & 0,8 & 0,3 & 0,6 & 0,3 & 4,8 \\
\hline $\mathrm{H}$ - gminy z intensywnie rozwiniętą funkcją rolniczą & 1,6 & 0,9 & 1,0 & 0,3 & 1,3 & 0,3 & 0,3 & 1,7 & 1,0 & 0,3 & 8,7 \\
\hline I - gminy z umiarkowanie rozwiniętą funkcją rolniczą & 2,5 & 1,4 & 1,4 & 0,7 & 2,0 & 0,6 & 0,6 & 0,9 & 2,6 & 0,6 & 13,2 \\
\hline J - gminy ekstensywnie zagospodarowane & 0,9 & 0,5 & 0,4 & 0,2 & 0,5 & 0,2 & 0,3 & 0,3 & 0,7 & 0,6 & 4,7 \\
\hline Razem & 22,7 & 22,4 & 8,5 & 8,1 & 7,8 & 3,4 & 4,3 & 6,8 & 12,2 & 3,9 & 100,0 \\
\hline
\end{tabular}

Objaśnienia: a) MOF - Miejski Obszar Funkcjonalny.

Źródło: na podstawie danych GUS o wymeldowaniach i zameldowaniach urzędowych. Klasyfikacja gmin według P. Śleszyńskiego i T. Komornickiego (2016).

w bardziej zagregowanej formie zestawiono na rys. 3A, wyróżniając sześć kategorii obszarów wydzielonych na podstawie stopnia metropolitalności i funkcji gmin. $\mathrm{W}$ klasyfikacji tej połączono rdzenie miejskie $\mathrm{z}$ ich strefami podmiejskimi. Ujawniło się wyraźnie kilka prawidłowości. Po pierwsze, główne przepływy dotyczą kierunku „dół-góra”, zwłaszcza do najbardziej rozwiniętych aglomeracji tzw. wielkiej piątki (Warszawa, Trójmiasto, Poznań, Wrocław i Kraków). Po drugie, widać dość wyraźnie pominięcie szczebli pośrednich, $\mathrm{np}$. przemieszczenia z ośrodków lokalnych kierują się od razu na samą górę hierarchii funkcjonalnej.

Jeśli weźmie się pod uwagę potencjał demograficzny obszarów źródłowych, a następnie wartości przepływów odniesie do liczby mieszkańców (rys. 3B), ujawni się jeszcze inna prawidłowość: większą stałą mobilnością charakteryzują się regiony o niższej urba- nizacji. W 2009 r. zaobserwowano bowiem następujące wartości rejestrowanych odpływów w ruchu wewnętrznym na 1000 mieszkańców obszaru źródłowego:

a) z aglomeracji tzw. wielkiej piątki (Warszawa, Trójmiasto, Poznań, Wrocław, Kraków) - 3,3;

b) z aglomeracji ośrodków regionalnych (pozostałe miasta wojewódzkie oraz inne $\mathrm{z}$ miastem głównym >150 tys. mieszkańców) $-4,3$;

c) $\mathrm{z}$ aglomeracji subregionalnych (pozostałe miasta na prawach powiatu i byłe miasta wojewódzkie z ich otoczeniem) $-6,8$;

d) gminy miejskie i miejsko-wiejskie, będące stolicami powiatów - 8,5;

e) inne gminy miejskie i miejsko-wiejskie $-9,3$;

f) pozostałe gminy wiejskie - 10,1.

Średnia dla całego kraju wyniosła 6,7. 
Większa emisyjność terenów typowo wiejskich i „małomiasteczkowych”, jak też generalnie wyraźna prawidłowość polegająca na odwrotnie proporcjonalnej zależności odpływu od stopnia urbanizacji może ostrożnie wskazywać, że uruchomione zostały procesy związane z dokończeniem tzw. niepełnej urbanizacji. Możliwe ujawnienie się tego czynnika, związanego $\mathrm{z}$ przyśpieszeniem zmian strukturalnych $\mathrm{w}$ rolnictwie, było wskazywane jako jedne z istotniejszych w kształtowaniu (zasilaniu) miejskiego systemu osadniczego (Korcelli 1997, 2008).
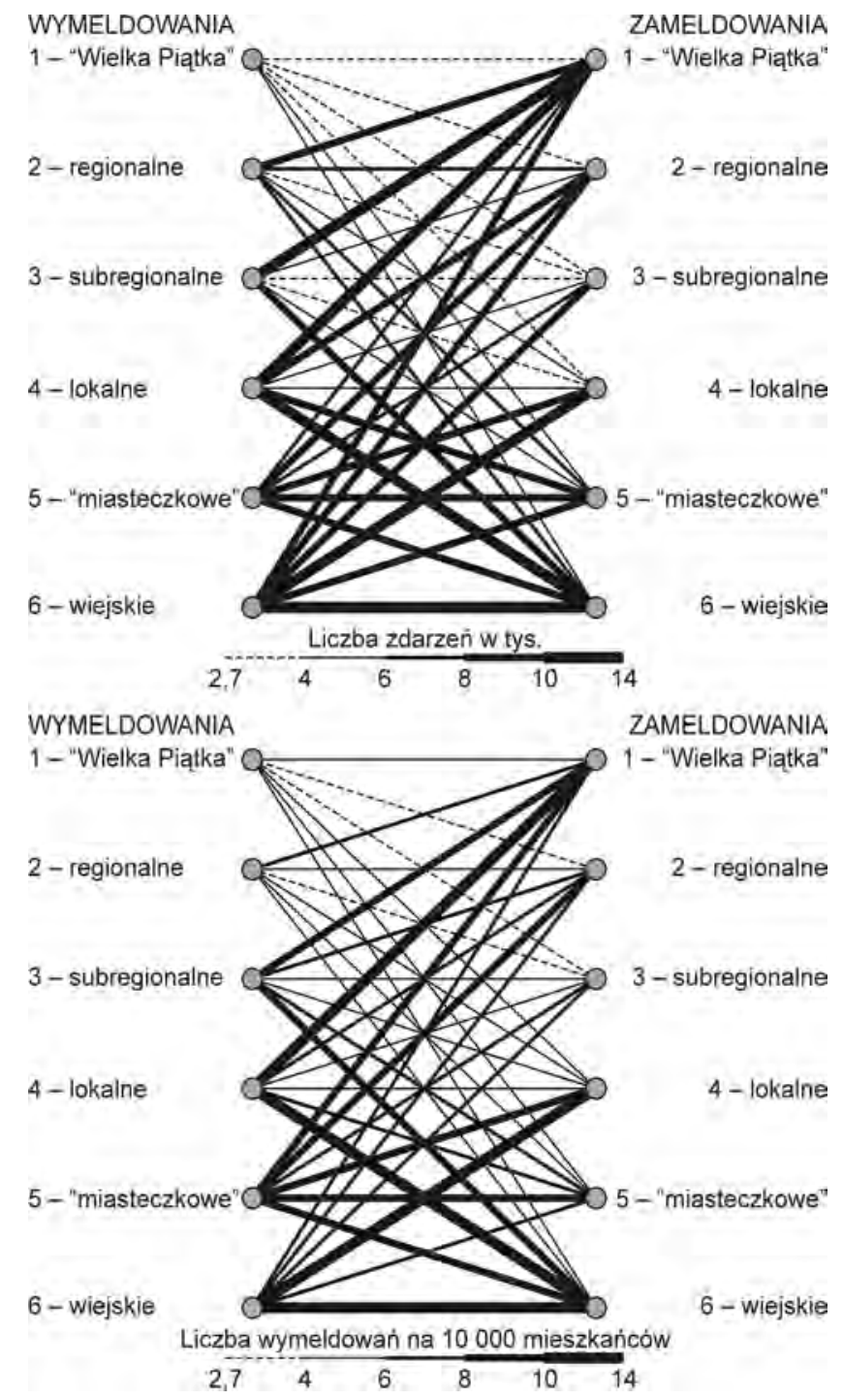

Rys. 3. Rejestrowane przemieszczenia migracyjne pomiędzy kategoriami gmin w $2012 \mathrm{r}$.

A - ogółem, B - na 1000 mieszkańców obszaru źródłowego Źródło: na podstawie danych GUS

Powyżej wskazany rozwój procesów byłby pożądany z punktu widzenia polityki regionalnej. Oznaczałby on wprawdzie silniejszą depopulację terenów wiej- skich, ale generalnie byłby mniejszym złem, bowiem prowadziłby do osłabiania spodziewanej depopulacji miast, jak też wymusiłby lepszą organizację lokalnych systemów osadniczych przy rozproszonym osadnictwie wiejskim (uwarunkowanym historycznie i współcześnie).

\section{PROGNOZY DEMOGRAFICZNE I WPEYW DEPOPULACJI NA SYSTEM OSADNICZY}

W najbliższych dekadach spodziewana jest silna depopulacja Polski. Kolejne prognozy GUS wprawdzie odkładają ten problem w czasie (rys. 4), jednak kierunek zmian (o ile nie zajdą poważniejsze niespodziewane zmiany) jest nieuchronny. Warto podkreślić, że prognozy GUS bazują na zameldowanej na stałe populacji kraju, stąd faktyczny prognozowany wymiar depopulacji będzie znacznie większy, bądź już w znacznym stopniu do-tyczy niektórych części kraju. Wiąże się to z przebywaniem za granicą stosunkowo dużej populacji, szacowanej (według cytowanych danych BAEL) na 2,3 mln osób (2015 r.), z których według różnych szacunków 50-75\% nie powróci już do kraju.

Brak wymeldowania dużej grupy osób z powodu emigracji zagranicznej i ujmowanie ich $\mathrm{w}$ statystyce skutkuje dwojako na wyniki opracowywanych projekcji demograficznych (Śleszyński 2014d). Po pierwsze stany wyjściowe prognoz są zawyżone w stosunku do rzeczywistej liczby ludności. Po drugie przeszacowana ludność wpłynie odpowiednio ujemnie na liczbę i strukturę zdarzeń demograficznych w kraju w przyszłości. $\mathrm{Z}$ tego powodu można spodziewać się niższej globalnej płodności, a w perspektywie roku 2050 - mniejszej liczby ludności w wieku poprodukcyjnym.

Znając te uwarunkowania podjęto $\mathrm{w}$ artykule próbę oszacowania wpływu nierejestrowanych emigracji zagranicznych na liczbę ludności miast w perspektywie $2050 \mathrm{r}$. W tym celu posłużono się ostatnią prognozą GUS z 2014 r. w podziale na powiaty, z wyróżnieniem miast powiatowych grodzkich (rys. 5). Metodologia szacunku była następująca. Najpierw z danych BAEL przyjęto liczbę osób pozostających poza granicami kraju powyżej trzech miesięcy (2320 tys. w końcu 2014 r.). Według GUS około 80\% tej liczby przebywa tam powyżej 12 miesięcy (1856 tys.). Dalej przyjęto arbitralnie, że 65\% z tej liczby pozostanie tam na stałe (według różnych badań jest to 50-75\%). Daje to kwotę 1206 tys. osób. Jest to liczba, o którą zawyżo- 


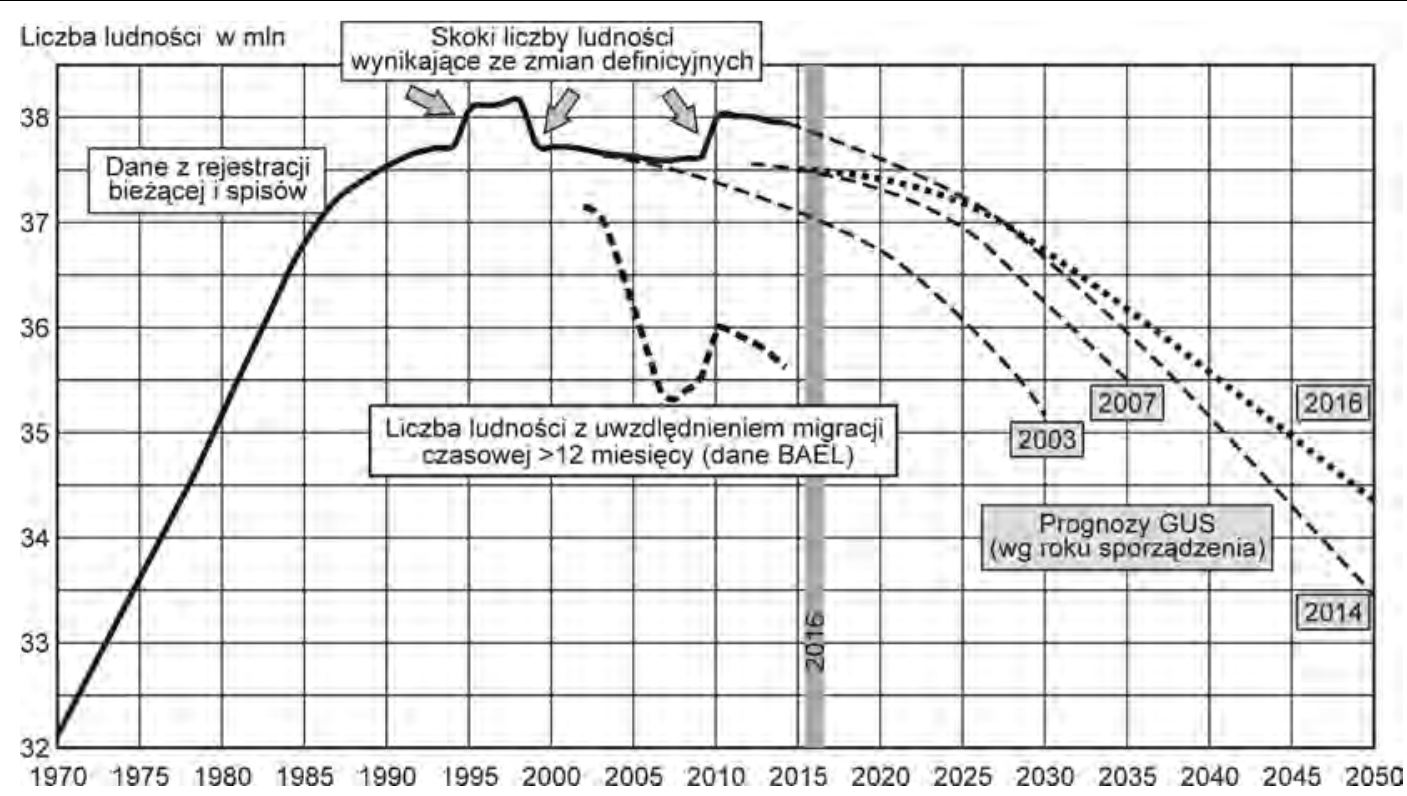

Rys. 4. Rozwój liczby ludności Polski w latach 1970-2050 według rejestrowanych i szacowanych przez GUS stanów liczby ludności oraz trzech ostatnich prognoz GUS (P 2003, P 2007, P 2014) Źródło: P. Śleszyński (2014c) - zaktualizowane

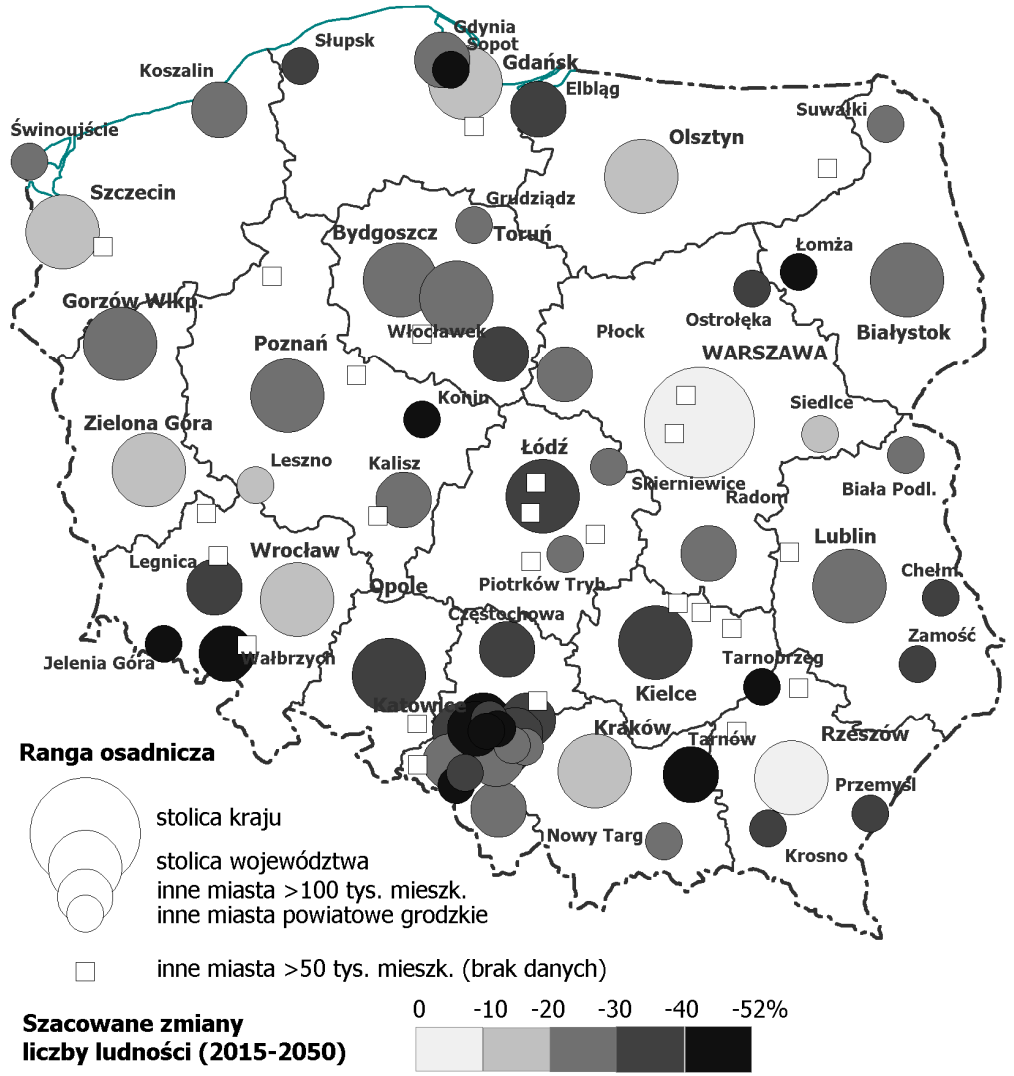

Rys. 5. Szacowany ubytek ludności do $2050 \mathrm{r}$. w miastach na prawach powiatu

Uwaga: ze względu na metodologię początkowy rok 2015 nie uwzględnia odpływu zagranicznego, rozłożonego w poprzednich latach (zwłaszcza w okresie poakcesyjnym).

Źródło: na podstawie prognozy GUS (2014), z uwzględnieniem tzw. czasowej emigracji zagranicznej ny jest stan wyjściowy prognozy GUS. Ma to dalej konsekwencje dla płodności ogólnej, bowiem ponad połowa tej liczby, to osoby w wieku produkcyjnym mobilnym (20-39) lat. Założono, że na każdą z tych osób mogłoby przypadać 0,75 dziecko (czyli 1,5 dziecko na parę) i o tyle zawyżona jest prognoza demograficzna GUS w przypadku oszacowania poziomu urodzeń (razem daje to dodatkowe 905 tys. osób). Łączne prze- 
szacowanie prognozy GUS obliczono zatem na 2111 tys. osób. O tę wartość skorygowano znane wyniki prognozy GUS według powiatów do 2050 r., przyjmując rozszacowanie na podstawie ostatniej znanej geograficznej struktury z NSP 2002 (Śleszyński 2013).

Spodziewana depopulacja miast będzie bardzo silna. Z aktualnych 12,6 mln mieszkańców miast powiatowych grodzkich ubędzie 3,0 mln mieszkańców, a więc prawie $1 / 4$. Ubytek jeszcze większy, sięgający nawet połowy ludności, będzie dotyczył m.in. niektórych miast konurbacji katowickiej (Bytom, Świętochłowice, Zabrze) i Tarnowa. Jednocześnie żadne $\mathrm{z}$ miast nie odnotuje wzrostu. W praktyce takie szanse ma jedynie Warszawa, w której istnieje pewna nadwyżka mieszkańców wynikająca $\mathrm{z}$ nierejestrowanych migracji wewnętrznych (według badań autora z 2005 i 2011 r., $\mathrm{w}$ granicach 110-230 tys.). Trzeba jednak zwrócić uwagę na fakt, że nadwyżka ta równocześnie oznacza zawyżenie liczby mieszkańców w innych regionach kraju, a więc odpowiednio gorsze przewidywania prognostyczne. Nie wiadomo, w jakim stopniu Warszawa "odbiera” zameldowanych mieszkańców obszarom wiejskim, a w jakim większym miastom.

W perspektywie 2050 r. należy zatem spodziewać się różnicowania miejskiego systemu osadniczego. Wzrośnie różnica pomiędzy największymi ośrodkami a miastami subregionalnymi. Oznacza to osłabienie policentryczności pod względem struktury wielkościowej miast.

Spodziewana depopulacja nastąpi, o ile nie zajdzie poważniejszy wzrost imigracji zagranicznej. Najnowsza prognoza GUS (2016), tzw. rezydencka, uwzględnia ten czynnik, poprzez przyjęcie stanów wyjściowych projekcji podwyższonych o liczbę rezydentów obcokrajowców.

Przedstawiona analiza jest przybliżonym, ale dość realnym szacunkiem, który mógłby być uszczegółowiony w przyszłości, pod warunkiem bardziej dokładnego rozpoznania nierejestrowanej (w postaci wymeldowania administracyjnego) emigracji zagranicznej. Równocześnie należałoby uwzględnić wpływ nierejestrowanych migracji wewnętrznych, istotnych zwłaszcza dla najbardziej atrakcyjnych miast i ich stref podmiejskich, np. Warszawy i Krakowa. Pod znakiem zapytania jest poziom imigracji zagranicznej.

\section{PODSUMOWANIE}

Analizy pokazują, że współcześnie zachodzą istotne zmiany związane z kształtowaniem miejskiego systemu osadniczego Polski pod względem czynników demograficzno-migracyjnych. Jeszcze bardziej spektakularnych zmian należy spodziewać się w przyszłości. Główne wnioski są następujące:

1. Wobec wyrównanego na ogół salda ruchu naturalnego, współcześnie czynnik migracyjny jest kluczowy dla kształtowania się miejskiej sieci osadniczej. W przyszłości ulegnie to zmianie i wraz $z$ postarzaniem struktury wieku coraz większe znaczenie będzie miało ujemne saldo urodzeń i zgonów.

2. Zachodzi różnicowanie zbioru miast pod względem struktury wielkościowej, które osłabia policentryczność. Najprawdopodobniej trend ten zostanie nie tylko utrzymany, lecz nawet wzmocniony.

3. W perspektywie 2050 r. należy spodziewać się silnych spadków liczby ludności miast - w niektórych sięgających 40-50\% populacji. Dla części miast może to oznaczać utratę dotychczasowej pozycji w systemie osadniczym.

4. Spadek liczby ludności może być częściowo łagodzony zwiększeniem imigracji zagranicznej, głównie z państw poradzieckich (Ukraina, w tym ludność pochodzenia polskiego).

5. Potrzebne jest przeformułowanie polityki rozwoju pod kątem szerszego włączania problematyki osadniczej. Dotyczy to m.in. efektywności układów osadniczych wobec rozpraszania zabudowy, zapewnienia standardu obsługi wraz ze starzeniem się populacji i możliwym spadkiem dochodów budżetowych samorządów oraz reorganizacji sieci osadniczej w układach lokalnych i regionalnych.

6. Możliwe rozwiązania to wzmacnianie ośrodków subregionalnych i niektórych regionalnych (niewojewódzkich), zmiany w podziałach terytorialnych różnego szczebla, w tym łączenie gmin i powiatów (zwłaszcza tzw. gmin obwarzankowych). Potrzebna jest też dyskusja nad efektywnością aktualnego podziału administracyjnego na szczeblu wojewódzkim. 


\section{PRZYPISY}

${ }^{1} \mathrm{~W}$ artykule prezentowane są wyniki m.in. projektu pt. „Wpływ zmian demograficznych w Polsce na rozwój lokalny" (2010/13/B/ HS4/03495) finansowanego przez Narodowe Centrum Nauki

2 To spolszczenie anglojęzycznego terminu „shrinking cities” (lub „urban shrinkage”) nie jest precyzyjne, bowiem nie dotyczy przestrzennego (powierzchniowego) zmniejszania się miast, tylko zewnętrznych oznak recesji w postaci rejestrowanego spadku ludnościowego. Szczegółową analizę terminologiczną tego i pokrewnych pojęć zawierają prace I. Kantor-Pietragi (2014, s. 21-32) oraz pod red. T. Stryjakiewicza (2014, s. 10-12).

\section{BIBLIOGRAFIA}

Dehnel G., Gołata E., 2013, Rozbieżności szacunków NSP 2011 i BAEL, ,Taksonomia”, 20, s. 120-130.

Długosz Z., 2005, Population movements in large Polish cities in 1988-2002, „Bulletin of Geography. Socio-Economic Series”, 4, Toruń, s. 25-36.

Dhugosz Z., 2006, Migration of population in big polish cities as compared to smaller cities and towns in the light of selected parameters of the migration process, „Bulletin of Geography. Socio-Economic Series", 6, Toruń, s. 33-50.

Długosz Z., Biały S., 2015, Przemiany demograficzne w dużych miastach Polski na początku XXI w., [w:] M. Soja, A. Zborowski (red.), Miasto w badaniach geografów, 2, Wyd. IGiGP UJ, Kraków, s. 13-28.

Eberhardt P., 2012, Stopień trafności polskich prognoz demograficznych, „Czasopismo Geograficzne”, 83, 1-2, s. 3-28.

Eberhardt P., 2014, Fazy rozwoju demograficznego Polski, „Roczniki Nauk Społecznych", 6, 2, s. 135-160.

Gawryszewski A., 2011, Rozwój demograficzno-społeczny wielkich miast ${ }_{w}$ Polsce ${ }_{w} X X$ wieku, [w:] S. Kaczmarek (red.), Miasto: Księga jubileuszowa w 70. rocznice urodzin Profesora Stanisława Liszewskiego, Wyd. Uniwersytetu Łódzkiego, Łodź, s. 51-64.

Gołata E., 2013a, Spis ludności i prawda, „Studia Demograficzne”, $1(161)$, s. $23-55$

GUS, 2014, Prognoza ludności na lata 2014-2050, „Studia i Analizy Statystyczne", GUS, Warszawa.

GUS, 2015, Informacja o rozmiarach $i$ kierunkach czasowej emigracji z Polski w latach 2004-2014, Notatka informacyjna, GUS, Warszawa.

GUS, 2016, Prognoza ludności rezydującej dla Polski na lata 20152050, Departament Badań Demograficznych i Rynku Pracy GUS, Warszawa, http://stat.gov.pl/obszarytematyczne/ludnosc/ prognoza-ludnosci/prognoza-ludnosci-rezydujacej-dla-polskina-lata-2015-2050,8,1.html; 6.07.2016.

Iglicka K., 2011, Migracje długookresowe i osiedleńcze z Polski po 2004 roku - przykład Wielkiej Brytanii. Wyzwania dla statystyki i demografii państwa, Raporty i Analizy, 5, Centrum Stosunków Międzynarodowych, Warszawa.

Jaroszewska E., Stryjakiewicz T., 2014, Kurczenie się miast w Polsce, [w:] T. Stryjakiewicz (red.), Kurczenie się miast w Europie Środkowo-Wschodniej, Bogucki Wyd. Naukowe, Poznań, s. 67-78.

Jażewicz I., 2013, Miejska sieć osadnicza regionu nadmorskiego, Wyd. Naukowe Akademii Pomorskiej, Słupsk.

Jończy R., 2010, Migracje zagraniczne z obszarów wiejskich województwa opolskiego po akcesji Polski do Unii Europejskiej: wybrane aspekty ekonomiczne $i$ demograficzne, Instytut Śląski, Opole.

Jończy R., 2014, Problem nierejestrowanej emigracji definitywnej (emigracji zawieszonej) w badaniu procesów społeczno-gospodarczych na obszarach wiejskich, Prace Naukowe Uniwersytetu Ekonomicznego we Wrocławiu, 360, s. 11-18.

Kantor-Pietraga I., 2014, Systematyka procesu depopulacji miast na obszarze Polski od XIX do XXI wieku, Wyd. Uniwersytetu Śląskiego, Katowice.

Kędelski M., 1990, Fikcja demograficzna w Polsce i RFN (ze studiów nad migracjami zagranicznymi), „Studia Demograficzne”, 1 (99), s. 21-55.

Korcelli P., 1995a, Demograficzne uwarunkowania rozwoju Warszawy, [w:] R. Domański (red.), Strategie rozwoju wielkich miast, „Biuletyn KPZK PAN”, 169, Warszawa, s. 123-134.

Korcelli P., 1995b, Aglomeracje miejskie w latach 90. Powolny wzrost, umiarkowana polaryzacja, [w:] R. Domański (red.), Strategie rozwoju wielkich miast, „Biuletyn KPZK PAN”, 169, Warszawa, s. 43-58.

Korcelli P., 1997, The urban system of Poland in an era of increasing inter urban competition, „Geographia Polonica”, 69, s. 45-54.

Korcelli P., 2008, System osadniczy Polski - tendencje i uwarunkowania przemian, [w:] T. Markowski (red.), Koncepcja przestrzennego zagospodarowania kraju a wizje i perspektywy rozwoju przestrzennego Europy, „Studia KPZK PAN”, 122, Warszawa, s. 30-42.

Kowalewski A., Mordasewicz J., Osiatyński J., Regulski J., Stępień J., Śleszyński P., 2014, Ekonomiczne straty i społeczne koszty niekontrolowanej urbanizacji $w$ Polsce - wybrane fragmenty raportu, „Samorząd Terytorialny”, 25, 4 (280), s. 5-21.

Kupiszewski M., 2002, Modelowanie dynamiki przemian ludności w warunkach wzrostu znaczenia migracji międzynarodowych, „Prace Geograficzne”, 181.

Kurek S., 2002, Proces starzenia się ludności w powiatach miejskich na tle pozostałych jednostek osadniczych, [w:] J. Słodczyk (red.), Demograficzne i społeczne aspekty rozwoju miast, Uniwersytet Opolski, s. 103-116.

Paradysz J., 2009, Błędy pokrycia w Narodowych Spisach Powszechnych, [w:] J. Kolonko, W. Gamrot (red.), Statystyka w praktyce społeczno-gospodarczej, Wyd. Akademii Ekonomicznej w Katowicach, Katowice, s. 65-76.

Parysek J., 2005, Miasta polskie na przełomie XX i XXI wieku: Rozwój i przekształcenia strukturalne, Bogucki Wyd. Naukowe, Poznań.

Runge A., 2013, Rola miast średnich w kształtowaniu systemu osadniczego Polski, Wyd. Uniwersytetu Śląskiego, Katowice.

Sakson B., 1998, Szacunek rzeczywistej liczby Polaków, którzy opuścili kraj w latach 1981-1989 na podstawie danych Systemu Ewidencji Ruchu Paszportowego, „Studia Demograficzne”, $1(131)$, s. 27-66.

Stryjakiewicz T. (red.), 2014, Kurczenie się miast w Europie Środkowo-Wschodniej, Bogucki Wyd. Naukowe, Poznań.

Systematyka procesu depopulacji miast na obszarze Polski od XIX do XXI wieku, 2014, Wyd. Uniwersytetu Śląskiego, Katowice.

Szukalski P., 2014, Depopulacja dużych miast w Polsce, „Demografia i Gerontologia Społeczna - Biuletyn Informacyjny", 7, s. 2-5.

Szymańska D., Grzelak-Kostulska E., 2005, Problematyka małych miast $w$ Polsce $w$ świetle literatury, [w:] K. Heffner, T. Marszał (red.), Problemy rozwoju małych miast $w$ wymiarze lokalnym i regionalnym, „Biuletyn KPZK PAN”, 220, Warszawa, s. 21-38. 
Śleszyński P., 2005, Różnice liczby ludności ujawnione w Narodowym Spisie Powszechnym 2002, „Przegląd Geograficzny”, 77, 2, s. 193-212.

Śleszyński P., 2011a, Oszacowanie rzeczywistej liczby ludności gmin województwa mazowieckiego z wykorzystaniem danych ZUS, „Studia Demograficzne”, 2(160), s. 35-57.

Śleszyński P., 2011b, Social linkages, [w:] T. Komornicki, P. Siłka (red.), Functional linkages between polish metropolises, „Studia Regionalia", 29, s. 65-80.

Śleszyński P., 2013, Prawidłowości zróżnicowań przestrzennych emigracji zagranicznej z Polski po 1989 r., „Studia Migracyjne - Przegląd Polonijny", 39, 3, s. 37-62.

Śleszyński P., 2014a, Przemiany społeczno-demograficzne województwa mazowieckiego w latach 1990-2030, „Trendy Rozwojowe Mazowsza", 15, Mazowieckie Biuro Planowania Regionalnego, Warszawa.

Śleszyński P., 2014b, Procesy suburbanizacji w Polsce a polityka przestrzenna i regionalna, [w:] A. Wolaniuk (red.), Centra i peryferie w okresie transformacji ustrojowej, XXVII „Konwersatorium Wiedzy o Mieście", Wyd. Uniwersytetu Łódzkiego, s. $11-26$.

Śleszyński P., 2014c, Distribution of population density in Polish towns and cities, „Geographia Polonica”, 87, 1, s. 61-75.
Śleszyński P., 2014d, W sprawie prognozy demograficznej i jej niektórych skutków, [w:] Z. Strzelecki, E. Kowalczyk (red.), Przemiany ludności w Polsce. Przyszłość demograficzna. Konferencja jubileuszowa Rządowej Rady Ludnościowej, Zakład Wydawnictw Statystycznych, Warszawa, s. 152-156.

Śleszyński P., Komornicki T., 2016, Klasyfikacja gmin Polski na potrzeby monitoringu zagospodaroowania przestrzennego, „Przegląd Geograficzny", 88, 4, s. 469-488.

Śleszyński P., Andrzejewska M., Cerić D., Deręgowska A., Komornicki T., Rusztecka M., Solon J., Sudra P., Zielińska B., 2015, Analiza stanu $i$ uwarunkowań prac planistycznych $w$ gminach w 2014 roku, Instytut Geografii i Przestrzennego Zagospodarowania PAN na zlecenie Ministerstwa Infrastruktury i Rozwoju, Warszawa, mps, https://www.igipz.pan.pl/aktualnosc-zgmil/ items/381.html.

Zborowski A., Raźniak P., 2013, Suburbanizacja rezydencjonalna w Polsce - ujęcia badawcze i ocena procesu, „Studia Miejskie”, 9, s. 37-50.

Artykuł wpłyną: 14 czerwca 2016 Zaakceptowano do druku: 7 października 2016 